DOI: 10.21802/artm.2020.4.16. 21.

UDC 616.379-008.64+612.349.8+616.37+616-006.6+616.345

\title{
INSULIN RESISTANCE IN PATIENTS WITH PANCREATIC AND COLORECTAL CANCER DIAGNOSED AGAINST THE BACKGROUND OF TYPE 2 DIABETES MELLITUS
}

\author{
T.S. Vatseba
}

\author{
Ivano-Frankivsk National Medical University, Department of Endocrinology, Ivano-Frankivsk, Ukraine, \\ ORCID ID: 0000-0001-7849-2242, e-mail:tamara.vatseba@gmail.com
}

\begin{abstract}
The aim of the study was to investigate insulin resistance in patients with pancreatic and colorectal cancer diagnosed in people with type 2 diabetes.

Materials and methods. 64 patients were examined. They were divided into the following groups: group I healthy people (control group) $(\mathrm{n}=16)$; group II - patients with type 2 diabetes without cancer $(\mathrm{n}=28)$; group IIIa patients with type 2 diabetes with pancreatic cancer $(n=10)$, group IIIb - patients with type 2 diabetes with colorectal cancer $(n=10)$. The study involved patients from specialized departments of the Ivano-Frankivsk Regional Hospital and the Precarpathian Clinical Oncology Center.

Blood insulin levels were determined by enzyme-linked immunosorbent assay, using Insulin ELISA diagnostic kits, EIA-2935. Fasting blood glucose was determined by glucose oxidase method. Compensation for diabetes was assessed by the level of glycated hemoglobin (HbA1c) and determined by ion exchange chromatography. Data analysis was performed using Statistica 12.0 (StatSoft Inc., USA). Differences between the values in the comparison groups were determined by Student's t-test and were considered significant at $\mathrm{P}<0.05$.
\end{abstract}

Results. Patients with type 2 diabetes who were diagnosed with pancreatic cancer or colorectal cancer were older, compared with patients with type 2 diabetes without cancer $(\mathrm{P}<0.05)$. Obesity was diagnosed in patients with colorectal cancer of group IIIb, their BMI was higher in comparison with patients of group IIIa who suffered from pancreatic cancer $(\mathrm{P}<0.05)$. BMI in patients of group IIIa was lower than in control group $(\mathrm{P}<0.05)$, in patients of group II $(\mathrm{P}<0.05)$ and in patients of group IIIb with colorectal cancer $(\mathrm{P}<0.05)$.

Compared with patients of group II, patients with pancreatic and colorectal cancer had significantly lower insulin levels $(\mathrm{P}<0.05)$, but significantly higher fasting blood glucose levels $(\mathrm{P}<0.05)$. Insulin resistance according to the HOMA-IR index $(>3.0)$ was detected in both types of cancer. The HOMA-IR index in patients with pancreatic cancer was significantly lower than in patients of group II $(\mathrm{P}<0.05)$. The level of HbAlc in patients with type 2 diabetes without cancer and in patients with cancer diagnosed on the background of diabetes did not differ significantly $(\mathrm{P}>$ $0.05)$.

Prior to cancer detection, the same number of patients $(50.0 \%)$ received metformin-free therapy in both the pancreatic cancer group and the colorectal cancer group. However, the duration of diabetes in patients with pancreatic cancer was $2.90 \pm 2.60$ years and was significantly shorter than in patients with colorectal cancer $9.70 \pm 5.66(\mathrm{P}<0.05)$. $80.0 \%$ of patients in group IIIa had a history of diabetes less than 5 years, and $80.0 \%$ of patients in group IIIb - more than 5 years.

\section{Conclusions:}

1.In patients with type 2 diabetes mellitus with pancreatic cancer, as well as in patients with colorectal cancer, insulin resistance was detected by the HOMA-IR index, which depended on the combined effect of insulin and hyperglycemia in patients with colorectal cancer and on the fasting blood glucose in patients with pancreatic cancer.

2. The absence of hyperinsulinemia, the short duration of type 2 diabetes in patients with pancreatic cancer may be indirect evidence of cancer induced pancreatogenic diabetes (T3cDM) in the majority of patients of this group.

3. For elderly patients with newly diagnosed diabetes mellitus without obesity, without hyperinsulinemia, screening for pancreatic cancer is recommended.

Keywords: insulin resistance, diabetes mellitus, pancreatic cancer, colorectal cancer.

Introduction. Numerous scientific studies prove an increased risk of cancer in patients with type 2 diabetes mellitus (T2D) [1]. Given the rapid increase in the incidence of T2D, it is reasonable to expect an increasing frequency of cancer due to patients with diabetes.

Obesity, hyperinsulinemia and hyperglycemia are recognized as important factors of oncogenesis in patients with T2D [2]. It is known that about $80 \%$ of patients with T2D suffer from obesity, which is recognized as a favorable background for cancer due to chronic inflammation, activation of the body's immune system, insulin resistance, hyperglycemia and hyperinsulinemia [3].

Insulin resistance in T2D is associated with decrease of insulin sensitivity of muscle and adipose tissue and liver. There is an insufficient absorption of glucose by myocytes in muscular tissue, and in adipose tissue the insufficient influence of insulin promotes lipolysis, accumulation of free fatty acids (FFA) and atherogenic dyslipidemia. Insulin resistance of liver tissue causes a decrease in glycogen synthesis, activation of glycogenolysis and gluconeogenesis [4]. 
Assessment of insulin resistance in clinical practice is done by calculating the HOMA-IR index (Homeostasis Model Assessment of Insulin Resistance) according to the formula: HOMA-IR index = fasting blood glucose $(\mathrm{mmol} / \mathrm{l}) \mathrm{x}$ fasting insulin $(\mu \mathrm{IU} / \mathrm{l}) / 22.5)$. Normally, the number is $<3.0$. That is, both insulin levels and fasting blood glucose levels affect the HOMA-IR index.

Physiological metabolic and proliferative (in hyperinsulinemia) effects of insulin are realized after binding of the hormone to the insulin receptor (IR-A, IR-B) on cell membranes. After binding of insulin to IR-A, the insulin receptor substrate (IRS) is activated, which triggers the signaling pathways of phosphatidylinositol-3kinase (PI3K) and mitogen-activated protein kinase (MAPK), that are involved in both metabolic regulation and oncogenesis. Insulin and IGF-1-induced hyperactivation of PI3K has been shown to promote cell transition from the G1 to the S phase of the cell cycle, cell proliferation, and inhibition of apoptosis [5].

Hyperglycemia is the second important factor in oncogenesis in T2D. The direct dependence of proliferating cells on blood glucose levels has long been discovered by scientists. It has been shown that cancer cells require a powerful energy supply for division, which is mainly obtained by anaerobic glycolysis in conditions of insufficient blood supply and hypoxia [6]. The ability of hyperglycemia to affect the sensitization of proliferating cells to treatment has been proven [7].

Many studies have shown an increased risk of pancreatic and colorectal cancer in patients with T2D, explaining the mechanisms of association of two diseases due to obesity and insulin resistance $[8,9,10,11]$. However, there are scientific studies that do not link pancreatic cancer with obesity $[12,13]$.

The purpose of the study: to investigate insulin resistance in patients with pancreatic and colorectal cancer diagnosed in people with T2D.

Materials and methods. The study was conducted following the guidelines of the Declaration of Helsinki (1975) and its revised version of 1983. The study involved patients from specialized departments of the Ivano-Frankivsk Regional Hospital and the Precarpathian Clinical Oncology Center. 64 patients were examined. They were divided into the following groups: group I - healthy people (control group) $(n=16)$; group II patients with T2D $(\mathrm{n}=28)$; group IIIa - T2D patients with pancreatic cancer $(n=10)$, group IIIb - T2D patients with colorectal cancer $(n=10)$. Treatment of patients with T2D in groups II and III included various combinations of tablet antihyperglycemic drugs and insulin.

The level of blood insulin was determined by enzyme-linked immunosorbent assay in the interdepartmental scientific laboratory of IFNMU named after Academician Ye.M. Neiko on an automatic analyzer Stat fax 303+ (USA), using diagnostic kits Insulin ELISA, EIA-2935. According to laboratory kits, the normal insulin level was $2-25 \mu \mathrm{Mod} / \mathrm{ml}$. Fasting blood glucose
(FBG) was determined by glucose oxidase method. Compensation of diabetes mellitus (DM) was assessed by the level of glycated hemoglobin (HbAlc), determined by ion exchange chromatography, on an automatic analyzer BIO-RAD D-10 (USA).

Data analysis was performed using Statistica 12.0 (StatSoft Inc., USA) [14]. Differences between the values in the comparison groups were determined by Student's t-test and were considered significant at $\mathrm{P}<$ 0.05 .

Results. The results of patients with pancreatic and colorectal cancer were compared with the control group (group I) and with T2D patients without cancer (group II). Naturally, patients with T2D without cancer of group II, as well as patients with a combination of T2D and cancer in groups IIIa and IIIb, had different rates of carbohydrate metabolism, compared to the control group, namely higher levels of fasting glucose $(\mathrm{P}<0,05)$, HbA1c $(\mathrm{P}<0.05)$, HOMA-IR index $(\mathrm{P}<0.05)$ (table1).

According to the obtained data, patients of groups IIIa and IIIb were older than patients of the control group $(\mathrm{P}<0.05)$ and those with T2D in group II $(\mathrm{P}<$ $0.05)$. Body mass index (BMI) of patients with pancreatic cancer was $25.33 \pm 2.33 \mathrm{~kg} / \mathrm{m}^{2}$, which was significantly lower than in the control group $(\mathrm{P}<0.05)$, group II $(\mathrm{P}<$ $0.05)$ and group IIIb $(\mathrm{P}<0.05)$. BMI of patients with colorectal cancer of group IIIb was $32.86 \pm 2.58 \mathrm{~kg} / \mathrm{m}^{2}$, it met the criteria for obesity and was significantly higher than in patients with pancreatic cancer $(\mathrm{P}<0.05)$ (table $1)$.

In comparison with the data of patients of group II, patients of groups IIIa and IIIb had significantly lower insulin levels $(\mathrm{P}<0.05)$, but significantly higher fasting glycemia $(\mathrm{P}<0.05)$. The HOMA-IR index in patients with colorectal cancer did not differ from the values in group II, but in patients with pancreatic cancer it was lower than in patients of group II $(\mathrm{P}<0.05)$. In both types of cancer, the values of the HOMA-IR index met the criteria for insulin resistance $(>3.0)$ (table 1). The level of HbA1c in patients with T2D without cancer and in patients with cancer diagnosed on the background of diabetes did not differ significantly $(\mathrm{P}>0.05)$.

When comparing the duration of DM, it was found that before the diagnosing of cancer patients with pancreatic cancer of group IIIa had been suffering from T2D for a significantly shorter period of time compared with patients with colorectal cancer of group IIIb $(\mathrm{t}=$ $3.45, \mathrm{P}=0.003$ ) (table 1). The average duration of DM in patients of group IIIa was $2.90 \pm 2.60$ years, and in group IIIb $-9.70 \pm 5.66$ years. It was found that 8 out of 10 patients of group IIIa $(80.0 \%)$ had a history of T2D less than 5 years, while only 2 patients $(20.0 \%)$ of group IIIb had the same duration of DM.

The analysis of antihyperglycemic therapy of patients with a combination of T2D and pancreatic cancer (Fig. 1) and colorectal cancer (Fig. 2) was carried out. 
Table 1

Comparative characteristics of clinical and laboratory parameters of patients with T2D and patients with a combination of $T 2 D$ and cancer $(M \pm S D)$

\begin{tabular}{|c|c|c|c|c|c|c|c|}
\hline Groups & Age, years & $\begin{array}{l}\mathrm{BMI} \\
\mathrm{kg} / \mathrm{m}^{2}\end{array}$ & $\begin{array}{l}\text { Insulin, } \\
\mu \mathrm{Mod} / \mathrm{ml}\end{array}$ & $\begin{array}{l}\mathrm{FBG}, \\
\mathrm{mmol} / \mathrm{l}\end{array}$ & $\begin{array}{c}\mathrm{HbAlc}, \\
\%\end{array}$ & $\begin{array}{c}\text { Index } \\
\text { HOMA- IR }\end{array}$ & $\begin{array}{c}\text { Duration of } \\
\text { DM }\end{array}$ \\
\hline $\begin{array}{l}\text { Group I } \\
(\mathrm{n}=16)\end{array}$ & $\begin{array}{c}59.53 \pm \\
5.89\end{array}$ & $\begin{array}{c}29.72 \pm \\
2.79\end{array}$ & $\begin{array}{c}7.77 \pm \\
2.20\end{array}$ & $4.56 \pm 0.63$ & $5.81 \pm 0.55$ & $1.58 \pm 0.53$ & $\wedge$ \\
\hline $\begin{array}{l}\text { Group II } \\
(\mathrm{n}=28)\end{array}$ & $\begin{array}{c}56.07 \pm \\
6.87\end{array}$ & $\begin{array}{c}31.82 \pm \\
5.53\end{array}$ & $\begin{array}{c}23.60 \pm \\
10.83^{*}\end{array}$ & $\begin{array}{l}7.57 \pm \\
2.06^{*}\end{array}$ & $\begin{array}{c}7.99 \pm 1.50 \\
*\end{array}$ & $\begin{array}{c}7.62 \pm 3.21 \\
*\end{array}$ & $\begin{array}{c}11.38 \pm \\
8.28\end{array}$ \\
\hline $\begin{array}{c}\text { Group IIIa } \\
(\mathrm{n}=10)\end{array}$ & $\begin{array}{c}65.00 \pm \\
7.90 \\
* / * *\end{array}$ & $\begin{array}{c}25,33 \pm \\
2,33 \\
* / * *\end{array}$ & $\begin{array}{c}9.70 \pm \\
3.58 \\
* *\end{array}$ & $\begin{array}{c}11.31 \pm \\
2.81 \\
* / * *\end{array}$ & $\begin{array}{c}7.98 \pm \\
0.77 \\
*\end{array}$ & $\begin{array}{c}4.76 \pm \\
1.72 \\
* / * *\end{array}$ & $\begin{array}{c}2.90 \pm \\
2.60 \\
* *\end{array}$ \\
\hline $\begin{array}{c}\text { Group IIIb } \\
(\mathrm{n}=10)\end{array}$ & $\begin{array}{c}65.40 \pm \\
8.07 \\
* / * *\end{array}$ & $\begin{array}{c}32.86 \pm \\
2.58 \\
* / \#\end{array}$ & $\begin{array}{c}14.03 \pm \\
3.66 \\
* / * * / \#\end{array}$ & $\begin{array}{c}10.15 \pm \\
1.62 \\
* / * *\end{array}$ & $\begin{array}{c}8.02 \pm \\
1.31 \\
*\end{array}$ & $\begin{array}{c}6.45 \pm \\
2.45 \\
*\end{array}$ & $\begin{array}{c}9.70 \pm \\
5.66 \\
\#\end{array}$ \\
\hline
\end{tabular}

Notes: $1 .{ }^{*}$ - the difference is significant in comparison with the values of patients of group I; 2 . ** - the difference is significant in comparison with the values of patients of group II; 3 . \# - the difference is significant in comparison with the values of patients of group IIIa; $4 .^{\wedge}$ - in this group the values were not determined. The difference was determined using Student's t-test $(\mathrm{P}<0.05)$.

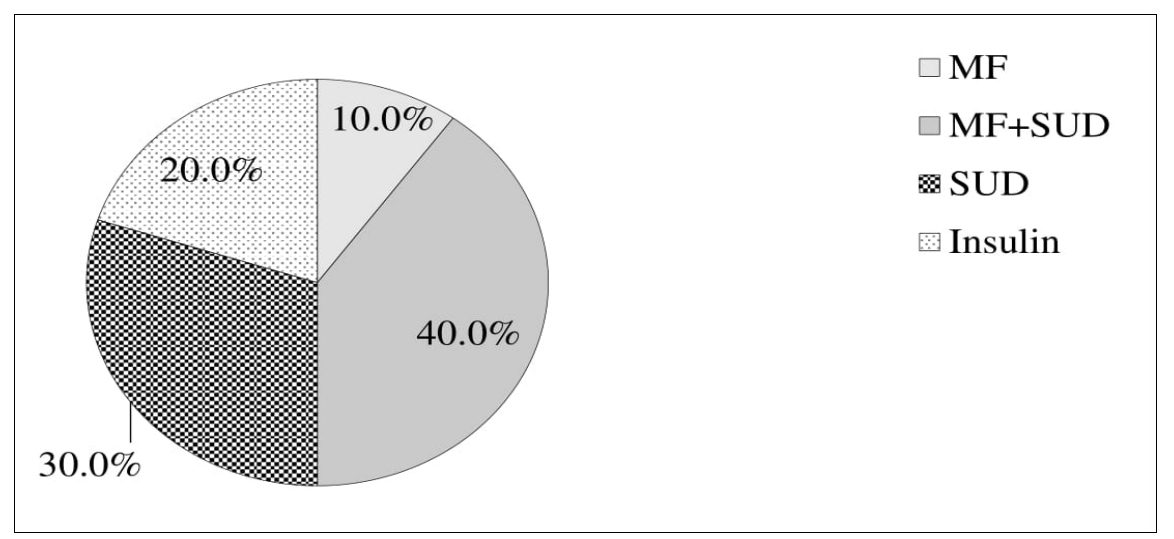

Fig. 1. Therapy schemes for T2D patients with pancreatic cancer

Note: MF - metformin; SUD - sulfonylurea derivatives.

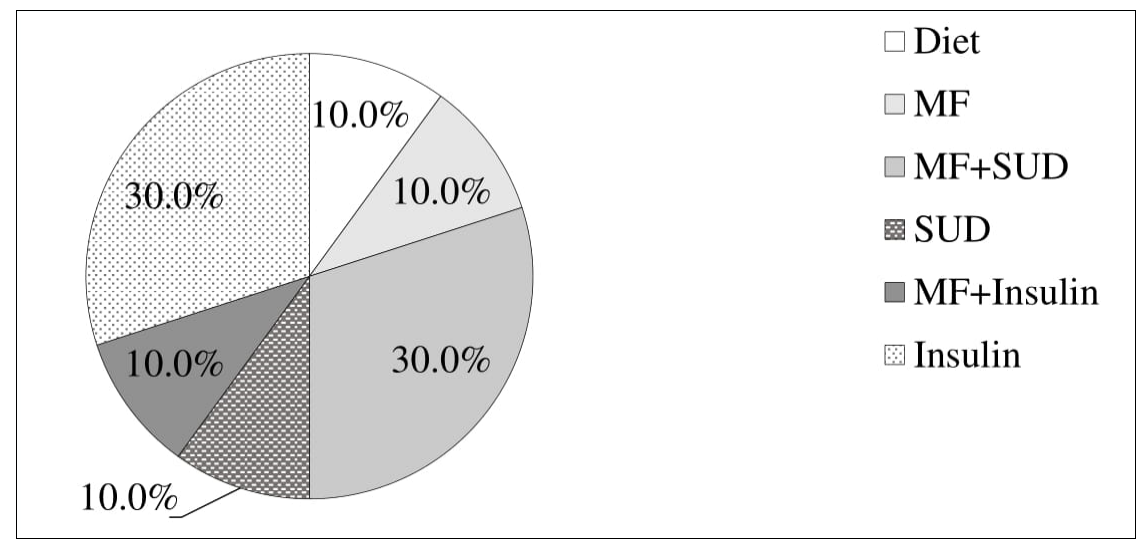

Fig. 2. Therapy schemes for T2D patients with colorectal cancer

Note: MF - metformin;

SUD - sulfonylurea derivatives.

According to the data obtained, before the diagnosing of cancer, patients equally often (50.0\%) used therapy without metformin (MF) in both IIIa and IIIb groups (Fig. 1, Fig. 2). However, the duration of DM was significantly different (table 1).

Discussion. The age characteristics of patients in group IV confirm that cancer is one of the diseases of aging [15]. One of the main theories of aging today is the influence of free radical damage [16] and the theory of pathological glycation of proteins [17]. It is known that in DM both types of processes are involved.

Aging processes involve the transition of cells to a senescent state, in which cells lose the ability to grow and divide, having reached the so-called Hayflick replication limit. However, at the molecular level, the effect of chronic pathological destabilizing signals on tumor sup- 
pressor genes can stimulate the proliferation of malignant cells. Overexpression of growth factors (insulin and IGF1) and cytokines has been recognized as a signal that induces premature aging in patients with T2D [15]. Hyperinsulinemia is a consequence of insulin resistance in T2D.

The obesity in patients with colorectal cancer explains the insulin resistance. Their HOMA-IR index exceeded 3.0. Insulin levels in patients of group IIIb were higher than in the control group $(\mathrm{P}<0.05)$ but did not exceed the reference values (according to laboratory kits). Probably, in patients with colorectal cancer, insulin resistance was due to the combined effects of insulin and hyperglycemia, which was reflected in the results of mathematical calculations of HOMA-IR index.

Insulin and the associated IGF-1 are physiological activators of the intracellular "insulin" signaling pathway PI3K/Akt/mTOR through which their effects, in particular regulation of synthesis of proteins, are realized. In conditions of insulin resistance, the chronic effect of hyperinsulinemia leads to excessive stimulation of this signaling system and disruption of the processes regulated by it [18].

The absence of severe hyperinsulinemia in patients of group IIIb proves the findings of research on two possible pathogenetic processes, which play an important role in the genesis of T2D: insulin resistance and dysfunction of $\beta$-cells. Moreover, these processes can be independent. It has been proven that the manifestations of $\mathrm{T} 2 \mathrm{D}$ occur when insulin production by $\beta$-cells is reduced by $50.0 \%$. Hyperglycemia is often diagnosed in patients without obesity and insulin resistance. Studies have shown that diabetes persists even after restoration of cell sensitivity to insulin (after patients' weight loss) [19].

On the other hand, insulin resistance is revealed in many other pathological conditions without DM. It has been proven that not all obese people develop diabetes. The pancreas of obese patients increases insulin secretion to compensate for insulin resistance. It is known that people, who do not suffer from obesity, can also have insulin resistance, probably caused by other factors. Such factors include certain genetic defects in insulin receptors, autoimmune damage to insulin receptors, and the formation of antibodies to insulin. According to the study of Gerich JE., dysfunction of $\beta$-cells, as well as insulin resistance, are genetically determined and depend on family history and ethnicity. Among the causes of reduced function of the pancreas are the following: hereditary decrease in the mass of pancreatic cells, increased apoptosis and reduced cell regeneration, depletion of $\beta$ cells due to prolonged insulin resistance; decreased sensitivity due to chronic hyperglycemia, lipid toxicity, amyloid deposition in pancreatic tissue [20]. For group IIIb patients, many of these factors may play a role.

According to the results, insulin resistance (HOMA-IR index > 3) was also confirmed in T2D patients with pancreatic cancer, as well as in patients with colorectal cancer. However, the analysis of clinical characteristics and laboratory parameters (shown in table 1) indicates significant differences between patients of groups IIIa and IIIb. In particular, patients with colorectal cancer have obesity, elevated insulin levels (compared with controls), decompensated diabetes and, as a consequence, increased HOMA-IR index.

Insulin resistance in patients with pancreatic cancer of group IIIa is not the same as in patients with colorectal cancer. Patients in group IIIa are not obese, and their insulin levels do not differ significantly from those in the control group $(\mathrm{P}>0.05)$ and are lower than in patients with colorectal cancer and T2D patients without cancer. It is obvious that in patients of group IIIa the HOMA-IR index largely depends on the level of hyperglycemia. Therefore, in patients with pancreatic and colorectal cancer, the components that form the numerical value of the insulin resistance index are completely different.

The HOMA-IR index, obviously, does not reflect the true insulin sensitivity in patients of group IIIa. Therefore, assessing insulin resistance we should consider the clinical preconditions for its formation and the differentiated values of laboratory parameters that affect the calculation of the HOMA-IR index. It is believed that hyperinsulinemia is more reliably and positively correlated with insulin resistance [21].

Elevated $\mathrm{HbAlc}$ in patients with diabetes requires additional search for causes and mechanisms of decompensation. Determining the type of dominant disorders of carbohydrate metabolism is individual and important for choosing the right treatment regimen. One of the methods for determining disorders of insulin synthesis is the study of insulin secretion after glucose loading. Preferably (but not always) patients with T2D have a disorder of the early phase of insulin secretion in response to hyperglycemia. Individual determination of the phase of insulin synthesis in patients will facilitate the selection of the correct antidiabetic therapy. For example, patients with early-phase disorders will need secretagogues, glinides, or short-acting insulin. In disorders of the second phase insulin secretion, it is advisable to prescribe antidiabetic drugs with prolonged release or basal insulin [19.]. Today we can study the types of carbohydrate metabolism disorders in patients with diabetes using modern devices for continuous glucose monitoring (CGM).

With regard to patients with pancreatic cancer detected on the background of T2D, taking into account the lack of obesity, hyperinsulinemia, as well as the predominant influence of prandial hyperglycemia on the HOMA-IR index, we can conclude that the genesis of cancer in patients of groups IIIa and IIIb is different. Early use of sulfonylurea derivatives and insulin with a short history of T2D lets us to suggest that a significant proportion of patients in group IIIa may have cancerinduced diabetes type T3cDM. This proves the importance of screening for pancreatic cancer in patients with newly diagnosed T2D without obesity and without hyperinsulinemia [22].

Therefore, the results of the study indicate the need for a complex but individual approach to the examination and treatment of each patient. It is important to identify the mechanisms that cause diabetes decompensation: insulin resistance, or insulin deficiency, or their combination. In this case, it can be assumed that the determination of the HOMA-IR index is insufficient for this answer. It is necessary to have indicators of C-peptide, 
insulin, liver tests, lipid profile, fasting and postprandial glucose levels, as well as indicators of CGM. The obtained results can be the subject of the following scientific research.

\section{Conclusions:}

1. In patients with type 2 diabetes mellitus with pancreatic cancer, as well as in patients with colorectal cancer, insulin resistance was detected by the HOMA-IR index, which depended on the combined effect of insulin and hyperglycemia in patients with colorectal cancer and on the fasting blood glucose in patients with pancreatic cancer.

2. The absence of hyperinsulinemia, the short duration of type 2 diabetes in patients with pancreatic cancer may be indirect evidence of cancer induced pancreatogenic diabetes (T3cDM) in the majority of patients of this group.

3. For elderly patients with newly diagnosed diabetes mellitus without obesity, without hyperinsulinemia, screening for pancreatic cancer is recommended.

\section{References:}

1. Oberaigner W, Ebenbichler C, Oberaigner K, Juchum M, Schönherr HR, Lechleitner M. Increased cancer incidence risk in type 2 diabetes mellitus: results from a cohort study in Tyrol/Austria. BMC Public Health. 2014; 14:1058. doi:https://doi.org/10.1186/14712458-14-1058.

2. Tsilidis KK, Kasimis JC, Lopez DS, Ntzani EE, Ioannidis JP. Type 2 diabetes and cancer: umbrella review of meta-analyses of observational studies. BMJ. 2015; 350:7607. doi:https://doi.org/10.1136/ bmj.g7607.

3. García-Jiménez C, Gutiérrez-Salmerón M, ChocarroCalvo A, García-Martinez JM, Castaño A, De la Vieja A. From obesity to diabetes and cancer: epidemiological links and role of therapies. $\mathrm{Br} \mathrm{J}$ Cancer. 2016; 114(7):716-722. doi: https://doi.org/ 10.1038/ bjc. 2016.37 .

4. Pankiv VI. Tsukrovyy diabet: diahnostychni kryteriyi, etiolohiya, patohenez. Mizhnarodnyy endokrynolohichnyy zhurnal. 2013; 56(8):53-64.

5. Giovannucci E, Harlan DM, Archer MC, Bergenstal RM, Gapstur SM, Habel LA, Pollak M, Regensteiner JG, Yee D. Diabetes and cancer: a consensus report. Diabetes Care. 2010; 33(7):1674-85. doi: https://doi.org/10.2337/dc10-0666.

6. Vander Heiden MG, Cantley LC, Thompson CB. Understanding the Warburg effect: the metabolic requirements of cell proliferation. Science. 2009; 324(5930):1029-33. doi: https://doi.org10.1126/ science. 1160809 .

7. Young CD, Anderson SM. Sugar and fat - that's where it's at: metabolic changes in tumors. Breast Cancer Res. 2008; 10(1):202. doi:1 https://doi.org/ $0.1186 /$ bcr 1852 .

8. Cirillo F, Catellani C, Sartori C, Lazzeroni P, Amarri $\mathrm{S}$, Street ME. Obesity, Insulin Resistance, and Colorectal Cancer: Could miRNA Dysregulation Play A Role? Int J Mol Sci. 2019; 20(12):2922. doi: https://doi.org/10.3390/ijms20122922
9. Huxley R, Ansary-Moghaddam A, Berrington de González A, Barzi F, Woodward M. Type-II diabetes and pancreatic cancer: a meta-analysis of 36 studies. British Journal of Cancer. 2005; 92(11):2076-83. doi: https://doi.org/10.1038/sj.bjc.6602619

10. Muniraj T, Chari ST. Diabetes and pancreatic cancer. Minerva Gastroenterol Dietol. 2012; 58(4):331-45.

11. Pothuraju R, Rachagani S, Junker WM, Chaudhary S, Saraswathi V, Kaur S, Batra SK. Pancreatic cancer associated with obesity and diabetes: an alternative approach for its targeting. J Exp Clin Cancer Res. 2018; Dec, 19; 37(1):319. doi: https://doi.org/ 10.1186/s13046-018-0963-4.

12. Ewald N, Bretzel RG. Diabetes mellitus secondary to pancreatic diseases (Type 3c) are we neglecting an important disease? Eur J Intern Med. 2013; 24(3):203-6. doi: https://doi.org/10.1016/j.ejim. 2012. 12.017.

13. Vatseba T.S. Type 2 diabetes mellitus: a marker or a risk factor for pancreatic cancer? Clinical endocrinology and endocrine surgery. 2019; 3(67):45-52. http://doi.org/10.30978/CEES-2019-3-45.

14. STATISTICA (data analysis software system), version 12. StatSoft, Inc. USA: Tulsa; 2014. Available from: https://www.statsoft.com.

15. Campisi J. Aging, cellular senescence, and cancer. Annu Rev Physiol. 2013; 75:685-705. doi:http://doi.org/10.1146/annurev-physiol-030212183653.

16. Liguori I, Russo G, Curcio F, Bulli G, Aran L, DellaMorte D, Gargiulo G, Testa G, Cacciatore F, Bonaduce D, Abete P. Oxidative stress, aging, and diseases. Clin Interv Aging. 2018; 13:757-772. doi: http://doi.org/10.2147/CIA.S158513.

17. Fournet M, Bonté F, Desmoulière A. Glycation Damage: A Possible Hub for Major Pathophysiological Disorders and Aging. Aging Dis. 2018; 9(5):880900. doi: http://doi.org/10.14336/AD.2017.1121.

18. Vatseba TS. The role of insulin, IGF-1 and PRAS40 in the processes of oncogenesis in women with diabetes mellitus type 2 and endometrial Galician Medical Journal. 2019; 26(4). doi: http://doi.org/10.21802/ gmj.2019.4.7.

19. Gerich JE. Contributions of insulin-resistance and insulin-secretory defects to the pathogenesis of type 2 diabetes mellitus. Mayo Clin Proc. 2003; 78(4):447456. doi: http://doi.org/10.4065/78.4.447.

20. Kahn SE. Clinical review 135: The importance of beta-cell failure in the development and progression of type 2 diabetes. J Clin Endocrinol Metab. 2001; Sep, 86(9):4047-58. doi: http://doi.org/10.1210/ jcem.86.9.7713.

21. Kobylyak NM, Kyriyenko DV. Laboratorna diahnostyka okremykh komponentiv metabolichnoho syndromu. Medytsynskye aspekty zdorovya zhenshchyny. 2015; 8:75-86. Available from: http://nbuv.gov.ua/UJRN/mazv.

22. Andersen DK, Korc M, Petersen GM, Eibl G, Li D, Rickels MR, Chari ST, Abbruzzese JL. Diabetes, Pancreatogenic Diabetes, and Pancreatic Cancer. Diabetes. 2017; 66(5):1103-1110. doi: http://doi.org/ $10.2337 / \mathrm{db} 16-1477$. 
УДК 616.379-008.64+612.349.8+616.37+616-

$006.6+616.345$

\section{ІНСУЛІНОРЕЗИСТЕНТНІСТЬ У ХВОРИХ 3 ОНКОЛОГІЧНИМИ ЗАХВОРЮВАННЯМИ ПІДШЛУНКОВОЇ ЗАЛОЗИ ТА КОЛОРЕКТА- ЛЬНИМ РАКОМ, ВИЯВЛЕНИМИ НА ФОНІ ЦУКРОВОГО ДІАБЕТУ 2 ТИПУ}

\author{
Т.С. Вацеба
}

Івано-Франківський наиіональний медичний університет, кафедра ендокринології,

м. Івано-Франківськ, Україна,

ORCID ID: 0000-0001-7849-2242,

e-mail: tamara.vatseba@gmail.com

Резюме. Метою роботи було дослідити інсулінорезистентність у пацієнтів 3 онкологічними захворюваннями підшлункової залози (ПШЗ) та колоректальним раком, діагностованими на фоні цукрового діабету (ЦД) 2 типу.

Матеріали і методи. Обстежено 64 особи наступних груп: I - здорові (контрольна група) $(\mathrm{n}=$ 16); II - хворі з ЦД 2 типу $(\mathrm{n}=28)$; ІІІа - хворі на ЦД 2 типу та рак ПШЗ $(\mathrm{n}=10)$, IIIb - хворі на ЦД 2 типу та колоректальний рак $(\mathrm{n}=10)$.

Рівень інсуліну визначали імуноферментним методом, глікемію натще - глюкозооксидазним методом, $\mathrm{HbAlc}$ - методом іонообмінної хроматографії. Аналіз даних проводили в програмі Statistica 12.0 (StatSoft Inc., США). Відмінності між показниками визначали за t-критерієм Стьюдента i вважали достовірними при $\mathrm{P}<0,05$.

Результати. Виявлено, що у хворих ІІІа групи з раком ПШЗ ІМТ нижчий, ніж в осіб І групи ( $\mathrm{P}<$ $0,05)$ та інших груп $(\mathrm{P}<0,05)$, у хворих 3 колоректальним раком підтверджене ожиріння.

У порівнянні з хворими II групи, пацієнти 3 пухлинами ПШЗ та колоректальним раком мали нижчі рівні інсуліну $(\mathrm{P}<0,05)$, але вищі рівні глікемії натще $(\mathrm{P}<0,05)$. Інсулінорезистентність за індексом HOMA-IR виявлена при обох типах раку. Індекс HOMA-IR у хворих IIIa групи був нижчим, ніж у пацієнтів II групи $(\mathrm{P}<0,05)$. Хворі на рак ПШЗ мали меншу тривалість ЦД, ніж пацієнти 3 колоректальним раком $(\mathrm{P}<0,05)$.

\section{Висновки:}

1. У хворих на ЦД 2 типу з раком ПШЗ і 3 колоректальним раком виявлена інсулінорезистентність за показником індексу HOMA-IR, який у хворих 3 колоректальним раком зумовлений поєднаним впливом інсуліну та гіперглікемії, а в пацієнтів з раком ПШЗ - залежить від глікемії натще.

2. Відсутність гіперінсулінемії та коротка тривалість ЦД до діагностики раку ПШЗ можуть бути непрямими доказами рак-індукованого діабету T3cDM.

3. Хворим старшого віку з вперше виявленим ЦД без ожиріння, без гіперінсулінемії рекомендований скринінг на рак ПШЗ.

Ключові слова: інсулінорезистентність, цукровий діабет, рак підшлункової залози, колоректальний рак.
УДК 616.379-008.64+612.349.8+616.37+616-

$006.6+616.345$

\section{ИНСУЛИНОРЕЗИСТЕНТНОСТЬ У БОЛЬНЫХ С ОНКОЛОГИЧЕСКИМИ ЗАБОЛЕВАНИЯМИ ПОДЖЕЛУДОЧНОЙ ЖЕЛЕЗЫ И КОЛОРЕКТАЛЬНЫМ РАКОМ, ВЫЯВЛЕННЫ- МИ НА ФОНЕ САХАРНОГО ДИАБЕТА 2 ТИПА}

\author{
Т.С. Вацеба
}

\author{
Ивано-Франковский нащчиональный медицинский \\ университет, кафедра эндокринологии, \\ 2. Ивано-Франковск, Украина, \\ ORCID ID: 0000-0001-7849-2242, \\ e-mail: tamara.vatseba@gmail.com
}

Резюме. Целью работы было исследовать инсулинорезистентность у пациентов с онкологическими заболеваниями поджелудочной железы (ПЖЖ) и колоректальным раком, диагностированными на фоне сахарного диабета (СД) 2 типа.

Материалы и методы. Обследовано 64 человека следующих групп: I -здоровые (контрольная группа) (n=16); II - больные СД 2 типа $(\mathrm{n}=28)$; IIIа -больные СД 2 типа и раком ПЖЖ (n = 10), IIIb больные СД 2 типа с колоректальным раком $(\mathrm{n}=10)$.

Уровень инсулина определяли иммуноферментным методом, уровень глюкозы крови натощак глюкозооксидазним методом, HbAlc - методом ионообменной хроматографии. Анализ данных проводили с помощью программы Statistica 12.0 (StatSoft Inc., США). Различия между показателями определяли по t-критерию Стьюдента и считали достоверными при $\mathrm{P}<0,05$.

Результаты. Выявлено, что у больных Ша группы ИМТ ниже, чем у лиц I группы $(\mathrm{P}<0,05)$ и других групп (P < 0,05), у больных колоректальным раком подтверждено ожирение. По сравнению с больными II группы, пациенты с опухолями ПЖЖ и колоректальным раком имели более низкие уровни инсулина (P < 0,05), но более высокие уровни гликемии натощак $(\mathrm{P}<0,05)$. Инсулинорезистентность по индексу HOMA-IR обнаружена при обоих типах рака. Индекс HOMA-IR у больных IIIa группы был ниже, чем у пациентов II группы $(\mathrm{P}<0,05)$. Больные IIIa группы имели меньшую длительность СД, чем пациенты IIIb группы $(\mathrm{P}<0,05)$.

\section{Выводы:}

1. У больных СД 2 типа с раком ПЖЖ и с колоректальным раком обнаружена инсулинорезистентность по показателю индекса HOMA-IR, который у больных колоректальным раком обусловлен совместным влиянием инсулина и гипергликемии, а у пациентов с раком ПЖЖ - зависит от гликемии натощак.

2. Отсутствие гиперинсулинемии и короткая продолжительность СД до диагностики рака ПЖЖ могут быть косвенными доказательствами ракиндуцированного диабета T3cDM.

3. Больным старшего возраста с впервые выявленным СД без ожирения, без гиперинсулинемии рекомендован скрининг на рак ПЖЖ. 
Ключевые слова: инсулинорезистентность, сахарный диабет, рак поджелудочной железы, колоректальный рак.

Стаття надійшла в редакцію 30.102020 р. 